\title{
MƯANYAGOK SZAKÍTÓSZILÁRDSÁGÁNAK VIZSGÁLATÁRA ALKALMAS BERENDEZÉS TERVEZÉSE ÉS KIVITELEZÉSE
}

\section{DESIGN AND IMPLEMENTATION OF A TENSILE TESTING MACHINE}

\author{
Fábián Hunor, ${ }^{1}$ Gergely Attila ${ }^{2}$ \\ ${ }^{1}$ Sapientia Erdélyi Magyar Tudományegyetem, Marosvásárhelyi Kar, Mechatronika Szak, Marosvásárhely, \\ Románia, fabianhunor2@gmail.com \\ ${ }^{2}$ Sapientia Erdélyi Magyar Tudományegyetem, Marosvásárhelyi Kar, Gépészmérnöki Tanszék, Marosvá- \\ sárhely, Románia, agergely@ms.sapientia.ro
}

\begin{abstract}
The aim of this paper is to present the design and manufacturing process of a tensile testing machine capable of measuring the tensile strength of polymeric materials. The structure of the instrument is similar to that used in the industry; however, it is budget friendly. The instrument consists of a frame, and two screws which are driven by two stepper motors. An Arduino is used to control the mechanical part of the instrument and to connect it to the software.
\end{abstract}

Keywords: tensile properties, elongation, design, polymer, control.

\section{Összefoglalás}

A dolgozat célja egy, a polimerek uniaxiális szakítóvizsgálatára alkalmas berendezés tervezése és kivitelezése. A berendezés felépítése az iparban használt szakítógépek felépítéséhez hasonló, viszont egy költséghatékony megvalósítás. A berendezés felépítésében helyet kapott egy váz, két csavarorsó, melyek léptetőmotorokkal vannak meghajtva. A mechanikus részt egy Arduino egység vezérli és kapcsolja a számítógépen található kezelői felülethez.

Kulcsszavak: szakitószilárdság, megnyúlás, tervezés, polimer, vezérlés.

\section{Bevezetés}

A szakítóvizsgálatot mint anyagtudományi eljárást elsők között Leonardo Da Vinci végezte el, amelyet mai értelemben is nevezhetünk szakítóvizsgálatnak, hiszen számszerüen meghatározhatta az általa vizsgált huzal teherbírását. Maga az eljárás egyszerű volt: egy huzal végére egy kosarat erősített, amelybe homokot engedett, amíg az el nem szakadt. A mai tesztberendezéseknek az elve is ugyanaz, addig terhelik a próbatestet, amíg az tönkre nem megy. [1, 2]

A szakítóvizsgálat lényege, hogy meg tudjuk határozni az anyagok rugalmasságát, alakváltozó képességét, szilárdságát, anyagi mérőszámát, ezen tudás ismerete elengedhetetlen egy mérnök számára, aki egy új alkatrészt szeretne tervezni. [2]

A szakítószilárdság az anyagnak csak az állandó terheléssel szembeni szilárdságára ad rálátást, dinamikus igénybevétel esetén jóval kisebb erőnek tud ellenállni. A szakítószilárdságot a hőmérséklet növekedésével, általában csökkenő tendenciát mutat. A szakítóvizsgálat megállapítására az adott anyagból szabvány szerint elkészített próbatesten statikus szakítóvizsgálatot végzünk, ami azt jelenti, hogy lassan növeljük a húzóerőt, és közben a berendezés felveszi a feszültség-alakváltozás diagramját. A próbatest állandó terhelése közben két fontos feszültséget veszünk figyelembe: [3] 
- Folyáshatár $\left(R_{e}\right)$ - melyet a darab maradandó alakváltozás nélkül elvisel.

- Szakítószilárdság $\left(R_{m}\right)$ - törés nélkül kibírt legnagyobb feszültség.

A szakítóvizsgálat hitelességét és pontosságát maga a tesztberendezés határozza meg. Az iparban erre a célra használt legelterjedtebb gépek egy tengely mentén terhelik a munkadarabot. Ugyancsak ezen az elven müködik az általam tervezett és kivitelezett berendezés is, amely tartalmaz egy vázszerkezetet. Ez egyben biztosítja az egy tengely mentén történő elmozdulást és megfelelően masszív a berendezésre ható erők legyőzésére, két befogószerkezetet, amely segítségével rögzíteni lehet a próbatestet, egy erőmérő szenzort, egy elektromechanikus hajtást, amely a próbatestre ható terhelő erőt szolgáltatja, és nem utolsósorban egy vezérlést.

\section{A szakítógép bemutatása}

\subsection{A tervezési feladat bemenő adatai}

A tervezett berendezés müködésének elve nagyban hasonlít az iparban használatos szakítógépek működési elvéhez. A cél a berendezés megvalósításával az, hogy a Sapientia Erdélyi Magyar Tudományegyetem Marosvásárhelyi Karának Polimer laboratóriumi eszköztárát bővítse.

A tesztberendezés tervezésének alapjául a polietilén-tereftalát (PET) műanyag szakítószilárdsága szolgált. [4] Ez az érték az ISO-527-1 alapján fröccsöntési eljárással előállított, és $40 \mathrm{~mm}^{2}$ keresztmetszetű próbatesten 132 MPa. A szakításhoz szükséges húzóerő kiszámítható a keresztmetszet és a szakítószilárdság szorzataként, ami $5280 \mathrm{~N}$. Egy 1.2-es biztonsági tényezővel beszorozva határozható meg a gép által maximálisan kifejtetendő erő nagysága, 6336 N. 6500 N-ra történt a kerekítés. A meghajtás elektromechanikusan van kivitelezve, ami két léptetőmotorból és két csavarorsós erőátvitelből épül fel. Ebből következik, hogy a végső erőnek csak a fele terheli az egyik motort és csavarorsót, ezért egyszerü csavarorsós emelőre redukálódtak a számítások.

\subsection{A gép felépítése}

\subsubsection{Vázszerkezet}

A gép alapját egy $15 \mathrm{~mm}$ vastag OL50-anyagú lemez alkotja, amelyre két $20 \mathrm{~mm}$ átmérőjü rozsdamentes acélrúd van rögzítve. Az acélrudakon két lineáris csapágy kapott helyet, amelyek az egy tengely mentén történő elmozdulást biztosítják.

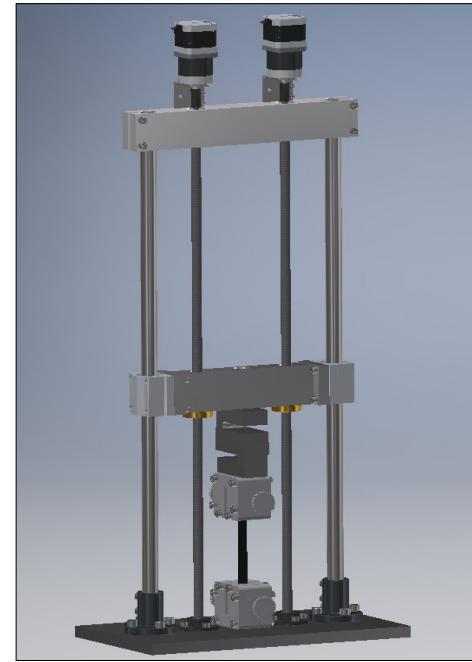

1. ábra. A tervezett szakítógép $3 D$ modellje

Ezáltal a tartórudak egyszerre több szerepet is betöltenek, tartják a motorokat, ezáltal felveszik az erőt, és megvezetik a középen elhelyezkedő mozgó keresztszánt. Fent található egy 6061-es típusú alumíniumból készült kötődarab, amelyen elhelyezkednek a motorok, és tartalmazza a csavarorsók csapágyazását.

\subsubsection{Csavarorsók}

A fentiekben megadott maximális erő értékéből kiszámítható a minimális orsó magátmérő, ez 6500 $\mathrm{N}$ felével egyenlő. Az orsó anyaga OLC45.

Az orsó magátmérőjének meghatározása:

$$
d_{2} \geq \sqrt{\frac{F}{\pi * \psi_{H} * \psi_{m} * \sigma_{m e g}}}=7,54 \mathrm{~mm}
$$

A képletben szereplő mennyiségek értelme a következő:

$\sigma_{m e g}-$ folyáshatár acél-bronz esetén,

$F$ - erő,

$d_{2}$ - mag átmérő,

$\Psi_{H}$ - csavarorsó menetprofil-magassági tényező, $\Psi_{m}$ - anya magassági tényezője.

Ezek az adatok következtében egy Tr12x3 trapézmenetes orsóra került a választás, ami $8 \mathrm{~mm}$-es magátmérővel rendelkezik, és hozzá bronzból készült anyák, az optimálisabb súrlódás érdekében

\subsubsection{Hajtás}

A berendezés működtetését két Nema 17-es léptetőmotor végzi, melyek egy i= 13,7 áttételi arányú fordulatszámcsökkentővel hajtják az orsókat [5]. Az erő értékéből és az orsó adataiból kiszámítható a szükséges forgatónyomaték értéke. 
A kívánt erő kifejtéséhez szükséges forgatónyomaték:

$M_{f}=F * \frac{d_{2}}{2} * \operatorname{tg}(\propto+\rho)=2.95 \mathrm{Nm}$

A képletben szereplő mennyiségek értelme a következő:

$M_{f} \quad$ - forgatónyomaték.

F - erő,

$d_{2} \quad$ - középátmérő.

a - trapézmenet dőlésszöge.

$\rho \quad$ - redukált súrlódási szög. [6]

A léptetőmotor folyamatos forgatónyomatéka $3 \mathrm{Nm}$, és pillanatnyilag $5 \mathrm{Nm}$-t is le tud adni, ezért erre esett a választás ebből a szempontból is. Másik és egyben fontosabb szempont a vezérlés részéről volt meghatározó, hisz a megnyúlás mérésére nem alkalmazunk külön szenzort, hanem programból figyeljük, vagyis a motor által megtett lépések számával egyenlő a megnyúlás, figyelembe véve az orsó menetemelkedését és a fordulatszám-csökkentő áttételi arányát. A motor 200 lépés megtétele után tesz meg egy teljes kört, az áttételi arány 13,7 és a menet emelkedése $3 \mathrm{~mm}$. Ezek segítségével megkapjuk, hogy 913 lépés megtétele után halad 1 mm-t a középső szán.

\subsubsection{Befogószerkezetek}

A próbatest úgy van kialakítva hogy a két szélén jóval szélesebb, ezt a méretet az ISO-527-1 írja elő, ami ebben az esetben $20 \mathrm{~mm}$. Erre a méretre lett tervezve a befogószerkezet, két mozgó pofával rendelkező csavarorsós satu. A satuk 6061-es típusú alumíniumból készültek CNC-vezérlésű marógépen.

A befogószerkezet (2. ábra.) három főbb alegységből tevődik össze, a külső szerkezetből, amely M6-os csavarokkal van összefogatva és két mozgó pofából, amelyek összeszorítják a próbatest szélét.

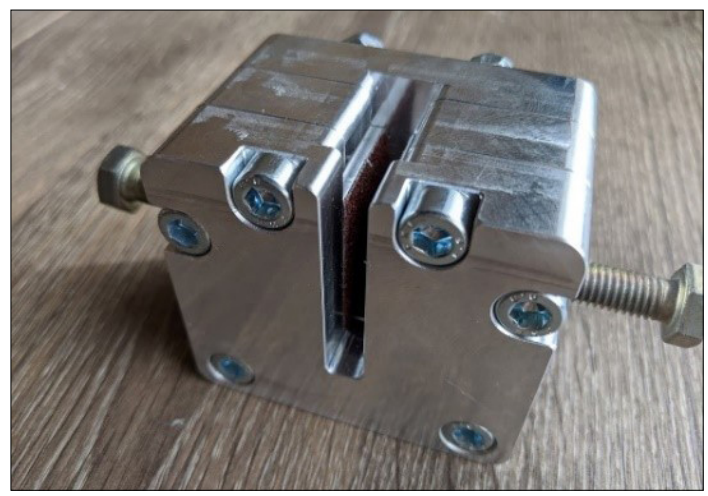

2. ábra. A befogószerkezet
A pofák felületére 80-as érdességű csiszolópapír van ragasztva, amely növeli a súrlódást a darab és a pofák közt. Két M8-as csavar a pofák mozgatását hivatott megoldani. A pofákban radiál-axiál csapágyak kaptak helyet, ezek felveszik a tengelyirányú erőket. A ház két szélébe M8-as menet van kialakítva.

\subsubsection{Csapágyazás}

A berendezésben két fajta csapágy kapott helyet, az első típus a lineáris csapágy, amely a megvezetőrudakon található, és lehetővé teszi a középső szán haladását. Ez golyós lineáris csapágy, amit az iparban előszeretettel használnak, egyszerűsége és költséghatékonysága miatt. Könnyen szerelhető, ebben az esetben M6-os csavarokkal van a középső szánhoz rögzítve. A másik típusú csapágy az axiál-radiál csapágy (3. ábra). Erre a típusra az orsóknál és a befogószerkezeteknél volt szükség, hiszen a csavarorsó által kifejtett húzó igénybevételnek és a pofákra ható szorítóerőnek is ellen kell, hogy álljanak. Az orsók esetében SKF-típusú golyós axiál-radiál csapágyak vannak használva 8 mm-es belső és 24 mm-es külső átmérővel, nem találtunk a piacon erre a típusú csapágyra gyártott csapágyházat, így a felső összekötő alumínium részében alakítottunk ki két csapágyházat. A szorítópofáknál ugyancsak SKF-típusú axiál-radiál csapágyak vannak alkalmazva, $4 \mathrm{~mm}$-es belső, illetve 13 mm-es külső átmerővel rendelkeznek. Ebben az esetben nem volt szükség külön csapágyházak alkalmazására, mivel magába a pofákba volt kialakítva a helyük, és a csavarosok is csapágyméretre vannak esztergálva.

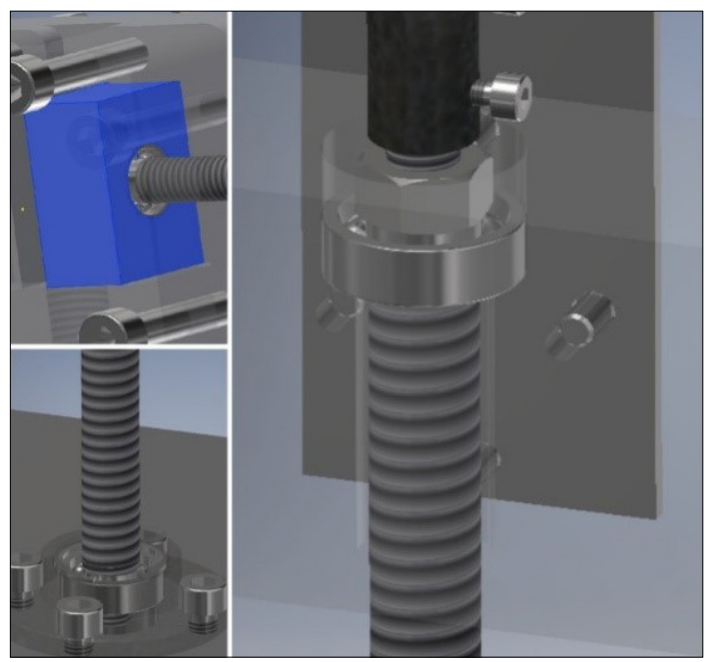

3. ábra. Radiál-axiál csapágyak,csapágyházastól 


\subsubsection{Erőmérő cella}

A próbatest elszakításához szükséges erő nagyságát egy STA-3-típusú analóg erőcella méri, melynek teherbírása $1000 \mathrm{~kg}$. [7] Ez a cella analóg jelet, vagyis feszültséget állít elő, amely egyenesen arányos az általa mért erő nagyságával. A cella által kibocsátott feszültség értéke $0-2 \mathrm{~V}$ között mozog. A tápellátását egy 12 voltos egyenáramú táp szolgáltatja. A befogószerkezet és a középső mozgószán között foglal majd helyet, és két darab M12-es csavarral lesz rögzítve a befogóhoz is, és a szánhoz is. Az általa kibocsátott feszültség értékét egy programozható mikrokontroller dolgozza fel, amely ebben az esetben egy Arduino Mega 2560.[8]

\subsubsection{Vezérlés}

A léptetőmotorok vezérlését egy DM33T-típusú digitális léptetőmotor-vezérlő végzi, amelyet a fentebb említett programozható mikrokontroller irányít. Az Arduinóban írt program utasításokat hajt végre, így vezérli a motrok forgásirányát és szögsebességét. Azért esett erre a típusú vezérlőre a választás, mert ipari felhasználásra van tervezve, megbízható és viszonylag könnyü programozni.

A bipoláris léptetőmotorok párhuzamosan bekötődnek megfelelően felcímkézett csatlakozókra. Az Arduino digitális pinjeire rákötődik a „PUL”-csatlakozó, amely a lépésekért felel, a „DIR”-csatlakozó, amely a forgásirányért felelős, és az „ENA”-csatlakozó, amely az 5 V-ba csatlakozik.

\subsubsection{Felhasználói felület}

A berendezés paraméterezését, mérési procedúrájának beállítását egy számítógépen futó szoftveres program végzi. Ez a felület egy Java-forráskódú, Eclipse fejlesztői környezetben valósult meg. A szoftver egy főablakkal indul, amelyben kiválaszthatjuk azt a soros portot, amelyen keresztül kommunikációt létesítünk az eszközünkkel. Miután kiválasztottuk ezt a beállítási lehetőséget, megjelenik a következő ablak, ahol manuálisan pozicionálhatjuk a befogószerkezetet, a nekünk megfelelő helyzetbe, a szakításra szánt próbatest méreteire. Továbbá lehetőségünkben áll kiválasztani a szakítási sebesség értékét, amelyet mm/percben adunk meg. Ha megtörtént a pozicionálás és a sebesség kiválasztása, nincs más dolgunk, mint elindítani a mérést a megfelelő gomb lenyomásával. Amíg a mérés folyamata tart, a harmadik ablak jeleníti meg online módon a szakítási diagramot. A mérés elvégzése után a felhasználónak lehetősége adódik a mérési adatok kimentésére egy .xlsx kiterjesztésű fájlba.

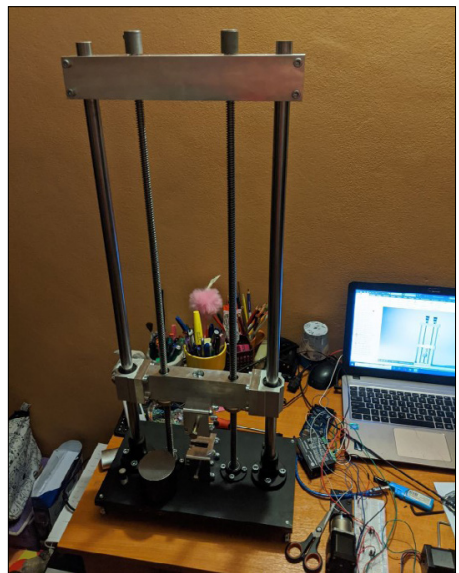

4. ábra. A berendezés megvalósított része

\section{Következtetések}

Következtetésként elmondhatjuk, hogy megterveztünk és részben megvalósítottunk (4. ábra) egy, a polimerek szakítóvizsgálatára alkalmas berendezést. A berendezés laboreszközként lesz használva a Sapientia Egyetem Marosvásárhelyi Karának Gépészmérnöki Tanszékén.

\section{Szakirodalmi hivatkozások}

[1]Tóth L., Rossmanith P.: A töréstechnika és az anyagvizsgálat története. Miskolci Egyetem, Miskolc, 1999. 4-10.

[2] Bitay E.: Anyagtudományi laboratórium I.: Tulajdonságminősítő vizsgálatok. Erdélyi Múzeum-Egyesület, 2011. https://doi.org/10.36242/mtf-11

[3] EN ISO 527: Plastics. Determination of tensile properties. 1994.

[4] Shimadzu Scientific Instruments, Columbia, MD: Testing the Tensile Properties of Rigid and Semirigid Plastics (ASTM D638 and ISO 527) (letöltve: 2020. február 20)

https://www.slideshare.net/ShimadzuSSI/testingthe-tensile-properties-of-rigid-and-semirigidplastics-astm-d638-and-iso-527

[5] Stepper Online: Nema 17 Stepper motor bipolar 17HS19-1684S-PG14 Datasheet. (letöltve 2020. február 20)

https://www.omc-stepperonline.com/download/17HS19-1684S-PG14.pdf

[6] Tolvaly-Roșca F.: Gépelemek. EME, 2019.

[7] OLCM Systems: STA-3 Alloy Steel S-Type Tension and Compression Load Cell. (letöltve 2020 feb. 20.) https://www.lcmsystems.com/sta-3-alloy-steel-stype-tension-and-compression-load-cell

[8] Arduino: Arduino Mega 2650. (letöltve 2020. február 20)

https://www.arduino.cc/en/pmwiki.php?n=Main/ arduinoBoardMega2560 